\title{
NEW HORIZONS IN THE ROLE OF LAW SCHOOLS IN TEACHING LEGAL ETHICS
}

\author{
ROBERT F. DRINAN, S.J."
}

\section{INTRODUCTION}

Law schools in America are facing crises that are difficult and unprecedented. From 1870 to 1945 , law schools instructed their students-who were mostly white men-in subjects that the students would need to be corporate lawyers and litigators. Revolution came to legal education in the 1950s and 1960s when blacks, women, and activists wanted to learn how to make law an instrument of change. Law schools changed slowly, but the changes accelerated after 1980 when international. studies, legal ethics, and women's studies radically altered the scene of legal education in America.

Those changes were created or at least greatly encouraged by foundation grants. The Ford Foundation gave substantial help and encouragement to programs in international law in America's law schools. Indeed, the impressive offerings in international studies that now characterize American legal education would in all probability not be there if the Ford Foundation had not given creative leadership. The surge of progress in the rights of women is likewise attributable to generous and creative grants by a wide variety of foundations and other entities. The same could be said for the emergence of the movement for clinical legal education.

Until the W.M. Keck Foundation initiated programs in legal ethics, the field of professional responsibility was in a real sense the orphan of the curriculum. Legal Ethics became a required course in the late 1970s, a development caused in part by the fact that twenty-eight lawyers were disciplined or convicted for their parts in the Watergate scandal. However, the requirement of this course both helped and hindered the development of the status of legal ethics as a respected discipline.

The establishment of the score of awards by the Keck Foundation created for the first time some outside initiative and enthusiasm to make legal ethics a much more vital and integral part of the curriculum of all law schools. A continuation and expansion of Keck grants will add important dimensions to the academic and professional content and orientation of America's law schools. Indeed, it might well bring about a moral rebirth of those ethical standards that the U.S. legal profession inherited from English jurists who created the common law.

Copyright $\odot 1996$ by Law and Contemporary Problems

* Professor, Georgetown University Law Center. 
One of the deepest moral convictions of the American legal profession has been that lawyers, as officers of the court, have a duty to make certain that the administration of justice serves everyone, including the poor. ${ }^{1}$ This noble commitment, inherited from the solicitors and barristers of England, has always been ambiguous and has often been honored in the breach.

\section{II}

\section{The Role of Law Schools in Teaching Legal ETHICS}

Law schools and bar associations will continue to explore the ethical reasons why lawyers have a unique obligation to render uncompensated service to the poor. Despite the well-documented fact that 80 percent of America's poor do not receive the civil legal services they need, it should be noted that law schools and lawyers have given more attention to legal ethics in the last ten years than in the previous one hundred.

Law schools, like everyone associated with the administration of justice in America, are searching for ways to correct the truly appalling fact that more than three-fourths of the nation's poor have inadequate access to any legal mechanism to vindicate their rights. For example, they are deeply involved in exploring the potential in fee-shifting statutes like the Civil Rights Attorney's Fees Act. ${ }^{2}$ This law, signed by President Ford in 1976, has been revolutionary in that it allows plaintiffs in civil rights cases to collect their counsel fees from the defendant if the plaintiff substantially prevails in the lawsuit. This measure has led to the enactment of similar statutes for plaintiffs in environmental and other types of cases. But the Act, however important, cannot be useful in the resolution of ordinary grievances such as landlord and tenant disputes, welfare benefits, or consumer complaints. Indeed the much-discussed idea of adopting the English rule that requires the unsuccessful plaintiff to pay the counsel fees of the defendant offers no hope for persons in America in need of legal services for routine grievances.

Why is it that the 800,000 attorneys in America can allow a situation to continue in which some 80 percent of poor citizens do not get through the door of the courtroom? Have the law schools failed to inculcate in their students an adequate knowledge of the history and the mission of the bar? Has legal education become so preoccupied with the exploration of knowledge that it has frequently forgotten the moral role lawyers have inherited from the majestic history of seven centuries of Anglo-American law?

1. For discussions of the pro bono obligations of attorneys, see Richard C. Baldwin, "Rethinking Professionalism"- and Then Living It!, 41 Emory L.J. 433 (1992); Jennifer Gerarda Brown, Rethinking "The Practice of Law," 41 Emory L.J. 451 (1992); Timothy P. Terrell \& James H. Wildman, Rethinking "Professionalism," 41 Emory L.J. 403 (1992).

2. 42 U.S.C. $\$ 1988$ (1976). 
Several areas of law and morality need to be revisited as law schools and the legal profession struggle to discover why America's poor are not obtaining the legal services they need and desire: the sense of injustice endemic to the legal profession; the efforts of religious law schools; the independence of the bar; and the emergence of internationally recognized human rights. Each of these will be discussed in turn.

\section{A. The Sense of Injustice Endemic to the Legal Profession}

Outrage at racial and gender discrimination is probably one of the main reasons why so many talented young men and women desire to go to law school. However, young adults in America do not as a rule react similarly to economic injustices. Women earn only 75 percent of every dollar a man makes. Every fourth child in America lives under the poverty line; every other black child is in that category. Millions of people are denied their rights as tenants or pension holders or employees. Nevertheless, the injuries inflicted by economic injustice do not cause the same level of moral outrage that is inspired by political or social discrimination.

How can law schools enlarge and deepen the desire to prevent injustice that most law students bring to law school? In a sense, every course in law school seeks to teach about equality, freedom, and justice. But do law schools concentrate too much on the rights of shareholders, corporations, and well-off clients? When students learn of their obligation under Model Rule $6.1^{3}$ to perform uncompensated service, they do not react favorably to this mandate as a way to serve the poor and the disadvantaged. Some students quarrel about, even resist what they consider an imposition.

How is it possible to instruct future attorneys so that they will act as responsible trustees of the monopoly granted to the legal profession by society and the courts? A good deal of legal history will be required before students will be able to grasp who they are in the majestic tradition inherited by them as members of the legal profession.

If law schools revisited and reanalyzed the moral teachings and traditions of lawyers dating back to the Magna Charta, the future attorneys of America would understand much more fully their moral obligation to insist that justice be done to every single citizen. English law had its limitations, but the moral role of the legal profession as it developed in England can only be described as inspiring. A lawyer is a highly skilled and highly trained individual, called to the bar, independent of any corporate or governmental demands and instructed to fight for justice for all persons, including the most unpopular ones.

This tradition is reflected in notable members of the bar in every generation of American jurisprudence. Yet, could it be that legal education has been distracted from its mission because it is smothered in the call for specialization, 
the overload of information, and the monetary rewards offered by wealthy corporations who want creative and ingenious attorneys?

If law schools stressed moral values and the need to fight injustice everywhere, could the scandal of 80 percent of poor Americans not being served by attorneys be corrected? It may be, however, that America's excessive commercialization makes it almost impossible for the law schools to do better than they do now in the inculcation of moral and ethical directives.

\section{B. The Efforts of Religious Law Schools}

The tradition of serving the poor has always been present in special and specific ways throughout the history of America's church-affiliated law schools. There are now twenty-four Catholic law schools in America, fourteen of which are under the auspices of a Jesuit university. Clearly, these law schools were established with the hope and expectation that the moral and religious mission of the parent university would be echoed and carried out in the law schools attached to these institutions.

In many instances, America's Catholic law schools can point to leaders of the bench and the bar who reflect the moral and Christian teaching taught at law school. In some cases, the Catholic influence can be traced to specific Catholic positions on issues such as divorce and abortion. In other cases, especially in more recent years, Catholic law schools have reflected their spiritual origins by stressing legal ethics, professional responsibility, and the full implications of natural law.

Georgetown University Law Center, established in 1870 by the Jesuit directors of Georgetown University, was one of the first university-related law schools in the United States. The Jesuit founders expected their law school to be an extension of the mission of Georgetown College, where the curriculum was heavily philosophical and theological in accordance with the Catholic tradition.

To some extent, that expectation was realized at Georgetown Law School. For several decades, the Catholic orientation of Georgetown University was reflected in the outlook of the law school. However, as society became more secularized and as other church-related universities lost some of their religious orientation, Georgetown Law School became less directly active in advancing moral or religious ideas.

But the anxieties and the aspirations within the legal profession during the last twenty-five years and the quest for more clarity and certainty about the objectives of law finally reached church-related law schools such as Georgetown. One of the manifestations of that phenomenon at Georgetown was the creation in 1987 of the Georgetown Journal of Legal Ethics, which has published more than 10,000 pages of articles and commentaries on every major problem in the expanding field of legal ethics. The Georgetown Journal of Legal Ethics has been regularly called the premier scholarly journal in its field; indeed, it is the only journal in the United States devoted exclusively to legal ethics. 
There are also eleven clinics at Georgetown Law School most of which are closely connected with providing legal representation for the poor. An additional clinic devoted to the advancement of internationally recognized human rights is being planned.

\section{The Independence of the Bar}

Law Day speeches revel in reminding lawyers that they are officers of the court and members of a profession that is independent. Both concepts need to be reanalyzed-especially the independence of the bar. ${ }^{4}$

Law schools in America tell their students vaguely and in almost a casual way that they are joining a profession that is "independent." But the concept is seldom analyzed, even in classes in professional responsibility or legal ethics. Independence means at least that lawyers are not the servants of the monied classes or the advocates of the status quo. Lawyers are not taxi drivers who must pick up every passenger. Lawyers can and should say no to some civil cases and causes. One example of the independence of the bar is the major stand taken by the American Bar Association recently when it declared that there was no need for either a constitutional amendment or a statute to criminalize burning of the flag.

By contrast, lawyers may be urged and indeed sometimes are required to take unpopular cases. The moral and ethical directives that bind attorneys recognize that the provision of legal services is essential even in unpopular cases if society wants to prevent the powerful from oppressing the powerless.

This need is reflected in the Code of Hammurabi, which defines the purpose of law to be to prevent the powerful from oppressing the powerless. In a sense, that phrase is the same as the concept of the independence of the bar. Lawyers must make judgments about the nature of justice and insist that the powerful extend equality and fairness to the powerless. American society assumes that lawyers are agents-indeed the exclusive ones-to help those without power to resist the intimidation of those with power.

The very concept of the independence of the bar assumes the existence of certain permanent moral values. It also assumes that the public at times will want to suppress unpopular minorities, allow economic giants to cheat consumers, and punish wrongdoers with a vengeance that is unfair. The legal profession possessed of independence will resist those proposals that go against

4. I never fully comprehended the meaning of the independence of the bar until I saw the way in which lawyers caved into dictators in nations like Argentina and Chile. Only a few lawyers in those nations resisted the tyranny of the military government. Most of the judges also capitulated to the displacement of the rule of law by the rule of naked power.

In Chile, a militant pro-democracy segment of the bar did organize and was eventually able to reassert the independence of the bar as practiced for many decades in the democratic rule that flourished before takeover by General Pinochet. However, Chilean lawyers and judges could have prevented or, at least, resisted the tyranny if they had had the conviction and courage to stand up for the rule of law. 
the basic moral values implicit in the centuries-old heritage of Anglo-American law.

Law schools cannot inculcate the riches and depths of the independence of the bar by one lecture or two. It may be conveyed to some extent if all the professors at a law school seriously permeate their courses with ethical concepts. But graduates of law school will not be imbued with a conviction of their exalted status as members of an independent profession unless some forgotten great moral traditions are recalled and revived in very creative ways.

A concrete way in which the Georgetown University Law Center has attempted to ingrain the concept of the independence of the bar has been through its program of helping black lawyers in South Africa to study for the LL.M. degree at Georgetown University. A dozen years ago, the Georgetown Law Center began an annual program of inviting five South African lawyers into its LL.M. program. In 1995, it had forty-one graduates preaching or teaching law in South Africa. In the summer of 1995, this writer, as a lecturer and consultant in South Africa, viewed first-hand the emphasis these forty-one attorneys have placed on the independence of the bar. Many of them were the architects of the new Constitution in South Africa who ensured the centrality of the concept of the independence of the bench and of the bar. These lawyers appreciated this idea before they came to Georgetown, but the marvelous evolution of the legal institutions of the new South Africa gave them even a deeper realization of its profound implications.

If law students learn to cherish the independence they have as members of the bar, could there be some startling changes in the way the administration of justice is carried out in America? Would the bar do something dramatic so that the poor could in fact have access to lawyers when they need them?

Ideas have consequences. And great ideas like the independence of the bar could have great consequences.

\section{The Emergence of Internationally Recognized Human Rights}

As the legal profession in America becomes more and more involved in the international dealings of multi-national corporations, American lawyers will be faced with the moral problems associated with doing business in nations that violate customary international law provisions regarding the protection of recognized human rights. The rights proclaimed in the universal declaration of human rights adopted by the United Nations in 1948 are now binding on all of the 187 countries in the U.N. Many of the rights defined in the several human rights covenants adopted by the U.N. and ratified by a large number of nations are also a part of customary international law; indeed, some of them have become jus cogens.

Consequently, there are new duties that are binding on American lawyers who participate in decisions made by clients who do business in nations where there is an institutionalized defiance of those human rights guaranteed by international law. Similarly, lawyers in the United States may not ethically be 
silent participants in the work of American corporations that openly violate basic U.S. laws, such as laws prohibiting discrimination in employment, the pollution of the environment, and contamination of consumer products.

The massive damages levied by the Resolution Trust Corporation against several American law firms employed by Mr. Charles Keating indicate that conduct of attorneys that rises to the level of collaboration in wrongdoing is unethical. The ethical norms developed in connection with the savings \& loan scandals-while not entirely clear or satisfactory-suggest that a new level of legal ethics may be in the process of development. The same conclusion regarding collaboration could be drawn for the evolution of the ethical norms that govern the conduct of lawyers assisting American corporations in their work in nations that openly violate internationally recognized rights.

In addition, American lawyers will begin to realize that their fellow attorneys in Asia and Africa are bound by the same international laws as they are-namely that they cannot participate in the conduct of clients that is clearly in violation of international standards agreed to by that nation or at least binding on that country by reason of its membership in the U.N. The universally accepted notion of the independence of the bar will be another reason why lawyers in America will find soulmates in foreign nations who recognize that complicity in the violation of international law is not ethically permitted of an officer of the court.

Some may feel that the increasingly binding power of international law may be a bit remote as a suitable topic to be included in the ethical norms taught to law students in America. Yet the role of the American bar in upholding and advancing international law is an essential part of the legacy and duty that is binding on America's 800,000 attorneys. Consequently, the ethical norms binding on attorneys in counseling their clients in international matters must be a part of the legal education of the attorneys who will be the leaders of the bar in the year 2020 .

III

\section{CONCLUSION}

Over the last generation, American legal education has improved in amazing ways. It has now achieved standards of academic and professional excellence never before realized since law schools began in the United States around the year 1850. A new emphasis on legal ethics would enrich that excellence.

Law school students today will be the leaders of the bench and the bar in the year 2020. At that time, the role and mission of the legal profession at home and abroad will be in all probability even more enormous than it is now. The international ethical norms regulating what American lawyers can and cannot do will be crucially important in the development of the rule of law in the more than 100 new nations in the developing world. 
What will law schools be like in 2010 or 2020 ? The needs that lawyers will have at those future dates are being discovered more and more rapidly. The needs that national and international entities will have for legal help are almost beyond comprehension.

The United States and nations of all kinds will need legal technicians and skillful mediators. More importantly, the world will need moral architects to streamline the United Nations, forge a permanent international criminal court like Nuremberg, create mechanisms to curb the international sale of arms, and develop ways to ensure that 800 million people are no longer chronically malnourished.

Lawyers have probably been more influential in the history of America than in any other nation. They have had that role because they are the wordsmiths for the moral concepts that constitute the heart of the American dream.

More than 100 nations that have been born from the ashes of colonialism since the end of World War II need the expertise and moral vision that are the very heart of the American legal profession. Law schools in the United States must be at the forefront in helping America's lawyers to share this legacy with nations that are anxious to further the protection of all human rights. 